INTERNATIONAL RESEARCH JOURNAL OF PHARMACY

www.irjponline.com

ISSN $2230-8407$

Review Article

\title{
ETHNOBOTANY, PHYTOCHEMICAL AND PHARMACOLOGICAL ASPECTS OF CINNAMOMUM ZEYLANICUM BLUME.
}

Das Manosi*, Mandal Suvra, Mallick Budhimanta and Hazra Jayram

National Research Institute of Ayurvedic Drug Development, Bidhannagar, Kolkata, West Bengal, India

Email: manosi_das@rediffmail.com

Article Received on: 20/02/13 Revised on: 01/03/13 Approved for publication: 21/04/13

DOI: 10.7897/2230-8407.04409

IRJP is an official publication of Moksha Publishing House. Website: www.mokshaph.com

(C) All rights reserved.

\begin{abstract}
Cinnamomum zeylanicum, popularly known as cinnamon or ceylon cinnamon refers to the tropical evergreen tree as well as the bark that is extracted from the plant. Cinnamon are recognized for its sweet flavour and aroma and used as an important spice in India in almost every delicious dishes . The spice has gained more importance due to its well uses as remedy for the treatment of various types of disorders in the Ayurvedic and folklore system of medicine in India from the era of "Charaka samhita". The herb is used for the treatment of dyspeptic conditions, flatulence, loss of appetite, abdominal pain with diarrhoea, inflammation of the eye, leukorrhoea, vaginitis, rheumatism, neuralgia, wounds, and toothache. The oil isolated from the different parts of the plant containing cinnamaldehyde and eugenol as major constituents are considered as active principle of cinnamon. Over the past two decades many scientific journals are describing its nutritional and medicinal properties. This review has tried to include an up to date phytochemical and biological research on cinnamon. The ethnobotanical uses have also been discussed.
\end{abstract}

Keywords: Cinnamomum zeylanicum, Indian spice, pharmacological activity, phytochemical, folklore, Ayurvedic

\section{INTRODUCTION}

Although there are several books on Indian spices ${ }^{1,2}$ but still now a complete coverage of phytochemical and pharmacological research on this spice (Cinnamomum zeylanicum) is very important and highly demanded. The herb which people use in daily food items is the best source for remedy or prevention of different ailments.

Cinnamomum zeylanicum Blume (Family Lauraceae) which is popularly known as cinnamon is classified in the botanical division Magnoliophyta, class Magnoliopsida. ${ }^{3}$ Generally in India, Cinnamomum zeylanicum is cultivated in south India. ${ }^{2}$ But it originates from the island of SriLanka (formerly called Ceylon), south east of India. Cinnamon spice is obtained by drying the central part of the bark and is marketed as quills or powder. The production of cinnamon is mostly limited to the wettest low land areas of South east Asia and cultivated up to an altitude of 500 meters above mean sea level having the mean temperature $27^{\circ} \mathrm{C}$ and annual rain fall $2000-2400 \mathrm{~mm}$. It prefers sandy soil enriched with organic matter. ${ }^{3}$ The genus cinnamomum has 250 species and many of them are aromatic and flavouring (Lee and Balick, 2005). ${ }^{4}$ There is very little distinction between Cinnamomum verum (syn. Cinnamomum zeylanicum, true cinnamon) and Cinnamomum cassia (Chinese cinnamon). Cinnamomum verum provides cinnamon bark of the finest quality and oil cinnamon whereas Cinnamomum cassia provides cassia bark and oil of Cassia (also known as oil of cinnamon). ${ }^{3}$

Common names of Cinnamomum zeylanicum Blume among the different races of India and in other countries are as follows: Bengali and Hindi -Dalchini, English:-Cylon cinnamon ,true cinnamon or cinnamon; Sanskrit-Tamalparta; Tamil-Ilayangam; Telgu-Lavanagamu; ${ }^{2}$ In Frenche cinnamon is known as Cammelle; In German-Ceylonzeimt/kaneel; In Spanish-canela. ${ }^{5}$

The tree grows to a height of 7-10 meters its wild state and has deeply veined ovate leaves that are dark green underneath,both bark and leaves are aromatic . It has small yellowish -white flowers with a disagreeable odour and bears dark purple berries. ${ }^{3}$
The pictures of different parts of Cinnamomum zeylanicum Blume are shown in Figure 1.

\section{Ethnobotanical Uses}

In Ayurvedic system, cinnamon (inner bark of shoots) is used in medicine preparation as flu-preventive, indigestion and flatulence control, bark is used in mouth washes. ${ }^{6}$ Cinnamomum zeylanicum is also used for the treatment of dyspeptic conditions such as mild spastic conditions of the gastrointestinal tract, fullness, and loss of appetite. It is also used to treat abdominal pain with diarrhoea, and pain associated with amenorrhoea and dysmenorrhoea.

Folk uses of cinnamon are found in the treatment of impotence, frigidity, dyspnoea, inflammation of the eye, leukorrhoea, vaginitis, rheumatism, neuralgia, wounds, toothache and diabetes. ${ }^{7}$

Cinnamomum zeylanicum is used as a minor constituent of Unani formulation "Jowarish Jalinoos" which is used in gastroenterological complaints and it is also used for the preparation of Ayurvedic Drug "Vyaghri Haritaki". 6

\section{Phytochemical Investigation}

Different parts (bark, roots, leaves, flowers, fruit stalks, buds) of the plant, Cinnamomum zeylanicum Blume, give essential oils with variation in the composition.

The active phytoconstituents of Cinnamomum zeylanicum Blume are Cinnamaldehyde and Eugenol. The 3D structure of these two phyto constituents are shown in Figure 2.

The variation of the composition of different parts of the plant, Cinnamomum zeylanicum Blume, are shown in Table 1 \&Table 2.

\section{Pharmacological Activity}

Antioxidant activity

Antioxidants are essential to the human body to neutralize free-reactive oxidant species.

In this study, acetone and methanol extracts of fresh and dry bark of Cinnamomum zeylanicum verum, were used for their antioxidant activity DPPH, ABTS and hydroxyl radical 
scavenging properties of both the extracts were found. Experiments were also conducted to evaluate the total phenolic content, the metal chelation capacity and the reducing power of extracts. The lipid peroxidation capacity of extracts was recorded using a linoleic acid emulsion system, which showed excellent results. Cytotoxic potential of extracts was also evaluated using MCF 7 cells. ${ }^{8}$

Moreover phenolic compounds such as hydroxycinnamaldehyde and hydroxycinnamic acid present in the cinnamon extract, act as scavengers of peroxide radicals and prevent oxidative damage. ${ }^{1}$

The total phenolics content of the extracts of dried fruit of cinnamon were found to be the highest water extract and showed strong antimutagenicity. ${ }^{1}$

In addition, cinnamon may serve as potential dietary sources of natural antioxidants for improving human nutrition and health.

Another investigation showed the antioxidative activity of cinnamtannin B1 isolated from Cinnamomum zeylanicum Blume was investigated. Antioxidants assay were carried out using lipid peroxidation by ferricthiocyanate (FTC) and DPPH radical scavenging analyzed with ultraviolet spectroscopy and electron spin resonance spectroscopic methods. Cinnamtannin B1 exhibited antioxidant activity in a series of in vitro test. It was found to be active and inhibited lipid peroxidation in ferric thiocyanate method. It was also an active scavenger of the radical 1,1-diphenyl-2-picrylhyrazyl which was analyzed with ultraviolet and electron spin resonance spectrometer with IC50 of $36 \mathrm{mM}$ and $0.2 \mu \mathrm{M}$ respectively. ${ }^{9}$

\section{Anti inflammatory activity}

Cinnamaldehyde inhibits nitric oxide production implicated in the inflammatory disease process and also demonstrated inhibition of cyclooxygenase-2 catalyzed prostaglandin E2 biosynthesis. The ethanolic extract $(70 \%)$ of cinnamon was effective on acute inflammation in mice. An herbal ophthalmic preparation, called ophtha care containing $0.5 \%$ cinnamon was found to be effective as anti-inflammatory agent on ocular inflammation in rabbits. ${ }^{2}$

\section{Antidiabetic activity}

Ethanolic extract of C. zeylanicum leaves possess a potent antidiabetic property as it significantly reduces the fasting blood sugar level in alloxon induced rats as compared to diabetic control group. ${ }^{10}$ Interest on cinnamon as a potentially useful treatment for type 2 diabetes began almost 20 years ago. An unidentified factor isolated from cinnamon and termed it as insulin potentiating factor (IPF). This IPF may be involved in the alleviation of the signs and symptoms of diabetes, and other diseases related to insulin resistance. ${ }^{11}$ The aqueous extract of cinnamon potentiated insulin activity more than 20-fold, higher than any other compound, tested at comparable dilutions in vitro in the epididymal fat cells. Cinnamon extracts showed to improve insulin receptor function by activating the enzyme that causes insulin to bind to cells (insulinreceptor- kinase) and inhibiting the enzyme that blocks this process (insulin-receptorphosphatase), leading to maximal phosphorylation of the insulin receptor, which is associated with increased insulin sensitivity. ${ }^{12}$ The unidentified factor present in cinnamon as methylhydroxychalcone polymer (MHCP)characterized and investigated its ability to function as insulin mimetic in 3T3L1 adipocytes.$^{13}$ The study analyzed that MHCP stimulated the autophosphorylation of the insulin receptor (IR), upregulated glucose uptake, glycogen synthesis and glycogen synthase (GS) activity in 3T3-L1 adipocytes, and downregulated glycogen synthase kinase-3 $\beta$ (GSK-3 $\beta$ ) activity. Glycogen synthesis stimulation is through a class I phosphatidylinositol (PI) 3-kinase dependent pathway. These events are all characteristic of 3T3- L1 adipocytes response to insulin. Moreover, the responses observed during the dual treatment were greater than additive, indicating synergism between the two compounds. Anderson et al. demonstrated that the in vitro insulin-potentiating activity found in cinnamon was present in the aqueous fraction. They suggested that the major active components in cinnamon are water soluble doubly-linked procyanidin type - A polymers, which were likely misidentified as MHCP in earlier studies . These polyphenolic compounds present as monomers or oligomers are responsible for in vitro insulin enhancing activity in epididymal fat cells. ${ }^{14}$ Cinnamon is reported to reduce the blood glucose level in non-insulin-dependent diabetics. Therapeutic studies have proved the potential of cinnamaldehyde as an antidiabetic agent. Cinnamaldehyde inhibits aldose reductase, a key enzyme involved in the 'polyol' pathway. This enzyme catalyses the conversion of glucose to sorbitol in insulin-insensitive tissues in diabetic patients. This leads to accumulation of sorbitol in chronic complications of diabetes, such as cataract, neuropathy and retinopathy. Aldose-reductase inhibitors prevent conversion of glucose to sorbitol, thereby preventing several diabetic complications. $^{15}$

\section{Antibacterial activity}

The essential oil of cinnamon is active in vitro against the following bacteria: Bacillus subtilis, Escherichia coli, Staphylococcus aureus, Salmonella typhimurium and Pseudomonas aeruginosa. Cinnamaldehyde and euginol (compounds of essential oil )proved to have antibacterial effects against Paenibacillus larvae. ${ }^{16}$ The proanthocyanidins-(epi)catechins from cinnamon bark exhibited strong antibacterial properties ${ }^{17}$ Cinnamaldehyde possessed strong antibacterial activity against nine strains of bacteria, including E. coli, P. aeruginosa, E. faecalis, $S$. aureus, Staphylococcus epidermidis, methicillin-resistant, $S$. aureus (MRSA), Klebsiella pneumoniae, Salmonella sp and Vibrio parahaemolyticus. ${ }^{2}$ Cinnamon bark oil showed inhibitory effect against the Gram- positive bacteria Bacillus cereus, Micrococcus luteus, and Enterococcus faecalis; the Gram-negative bacteria Alcaligenes faecalis, Enterobacter cloacae, Escherichia coli and the fungi Aspergillus niger and Rhizopus oligosporus; and the yeast Candida albicans. ${ }^{18}$

\section{Anti- fungal activity}

The antifungal properties of cinnamon have also drawn great attention from many researchers.. The effects of medicinal plant extracts on the development of mycelium of Phytophthora capsici, Rhizoctonia solani. Cinnamomum zeylanicum bark oil has fungitoxic properties against fungi involved in respiratory tract mycoses, such as Aspergillus niger, Aspergillus fumigatus, Aspergillus nidulans and Aspergillus flavus. ${ }^{19}$ Cinnamaldehyde and eugenol have also been demonstrated to have inhibitory properties against Aspergillus flavus, Aspergillus ochraceus, Aspergillus niger, Aspergillus terreus, Aspergillus citrinum, Penicillium viridicatum. ${ }^{20}$ The essential oil of cinnamon is active in vitro against the following fungi: Aspergillus spp., Cladosporium werneckii,Geotrichum candidum, Kloeckera apivulata, Candida lipolytica and Candida Albicans. ${ }^{17}$ 


\section{Insecticidal activity}

Cinnamaldehyde obtained from an extract of Cinnamomum cassia, is a potent insecticide against adults of Sitophilus orycaeand , Callosobruches chinensis. ${ }^{21}$ Repellent and insecticidal activities of essential oils extracted from leaves of Artemisia princeps and seeds of Cinnamomum camphora (L.) Presl against storage pests, Sitophillus oryzae L. and Bruchus rugimanus Bohem were investigated. Results showed that the two individual oils displayed good, but their mixture exhibited much better repellent activities. ${ }^{22}$ Cinnamon oil exhibited fumigant toxicity to adults of Acanthoscelides oblectusand which inhibited its reproduction through ovicidal and larvicidal action. Both cinnamaldehyde and cinnamyl alcohol showed ovicidal and larvicidal activity. Cinnamaldehyde possessed antifeedant activity against Ceratitis capitata, a pest causing damage to fruit crops .

\section{Nematicidal activity}

Cinnamon oil possessed strong nematicidal activity against the male, female and juveniles of pinewood nematode Bursaphelenchus xylophilus. ${ }^{23}$ Cinnamyl acetate, the active ingredient in the oil, at a concentration of $32.81 \mu \mathrm{g} / 1$ resulted in $50 \%$ mortality of nematodes, reported that at the rate of $0.2 \%$ ( weight by volume of soil) of stem bark of Cinnamomum cassi powder used for soil amendment significantly reduced by $91.1 \%$ gall number of Meloidogyne incognita infection (root gall formation) of tomato seedling compared with control. ${ }^{24}$
Antipyretic and analgesic activity

A decoction of dried twigs of cinnamon can produce an antipyretic effect in mice. Studies conducted in anaesthetized dogs and guinea pigs indicated that cinnamaldehyde, or sodium cinnamate, also produced the hypothermic and antipyretic effects. $^{25}$ It also causes a hypotensive effect, which is due mainly to vasodilation of peripheral vessels. Cinnamaldehyde produced an analgesic effect in mice. ${ }^{26}$ Nephritis is an autoimmune disease caused by activation of the complement system. Cinnamon cortex and cinnamon oil inhibited complement formation in vitro. Cinncassiol C1and its glucoside, the cinncassiols C2and C3and cinncassiol D and its glucoside were reported to possess anticomplementary activity. A water-soluble polysaccharide isolated from the cinnamon extract showed complement system activity. ${ }^{27} 2$ Hydroxycinnamaldehyde and 2-benzyloxy cinnamaldehyde isolated from the stem bark of cinnamon possessed immunomodulatory effects. ${ }^{2}$

\section{Antimicrobial activity}

Essential oils of cinnamon were found to possess antimicrobial properties. In vitro it inhibits the growth of Bacillus cereus ${ }^{28}$. Alcoholic extracts of cinnamon were found most effective against Helicobacter pylori in reducing its growth ${ }^{29}$. Cinnamon oil and extracts possess various antimicrobial activities against several bacteria, fungi, etc. Aqueous extract of (C. zeylanicum, Blume) inhibited the replication of the influenza virus.$^{30}$

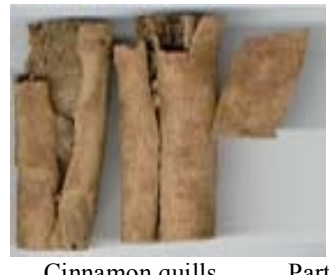

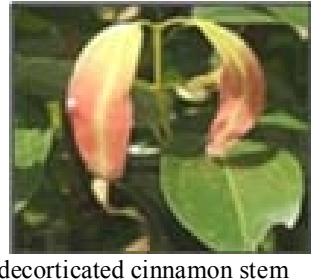

Figure 1

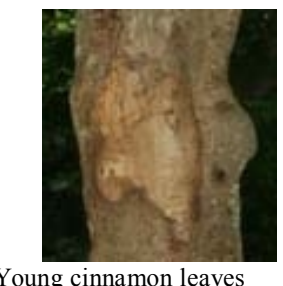

Young cinnamon leaves

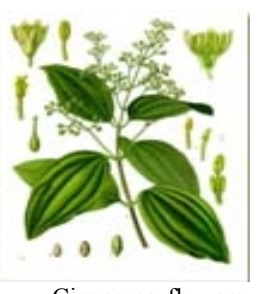

Cinnamon flowers

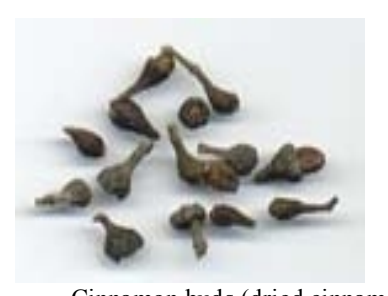

Cinnamon buds (dried cinnamon fruits) Figure 2

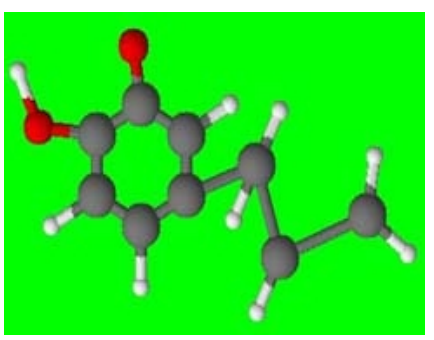

Structure of Cinnamaldehyde in 3D Active Phyto constituents of Cinnamomum zeylanicum Blume

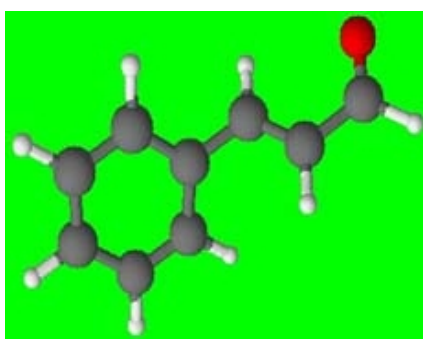

Structure of Eugenol in 3D

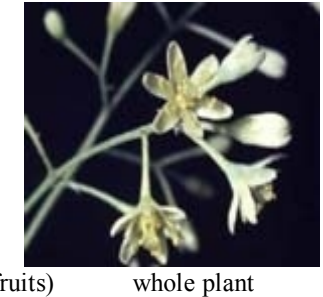

hole plant 
Das Manosi et al. Int. Res. J. Pharm. 2013, 4 (4)

Table-1 Volatiles from Cinnamomum zeylanicum Blume

\begin{tabular}{|c|c|c|c|c|c|}
\hline \multirow{2}{*}{ Compounds } & \multicolumn{5}{|c|}{ Plant part } \\
\hline & Leaf $^{31}$ & Stem bark $^{32}$ & Root bark ${ }^{32}$ & Flower $^{33}$ & Fruit $^{34}$ \\
\hline$n$-Hexanol & - & $\mathrm{t}$ & - & - & - \\
\hline$n$-Hexane-2-ol & + & - & - & - & - \\
\hline (Z)-Hex-3-en-1-ol & - & - & - & + & - \\
\hline Heptan-2-one & + & - & - & - & - \\
\hline $\boldsymbol{\alpha}$-Thujene & + & - & - & - & - \\
\hline $\boldsymbol{\alpha}$--Pinene & + & + & + & - & + \\
\hline Camphene & + & + & + & - & + \\
\hline Sabinene & + & + & + & - & - \\
\hline$\beta$-Pinene & + & + & + & - & + \\
\hline Myrcene & + & + & + & - & + \\
\hline -Phellandre & + & + & + & - & + \\
\hline$\Delta$-3-Carene & + & + & $\mathrm{t}$ & - & - \\
\hline$\alpha$-Terpinene & + & + & + & - & + \\
\hline$\gamma$-Terpinene & + & + & + & - & + \\
\hline p-Cymene & + & + & + & - & + \\
\hline 1,8-Cineole & + & + & + & - & + \\
\hline Limonene & - & + & + & - & + \\
\hline (E)- $\beta$-Ocimene & + & + & + & - & + \\
\hline$(Z)-\beta$-Ocimene & - & - & - & - & + \\
\hline transOcimene & - & $\mathrm{t}$ & + & - & - \\
\hline Cis-Ocimene & - & $\mathrm{t}$ & + & - & - \\
\hline 2-Phenylethylbenzoate & - & $\mathrm{t}$ & - & + & - \\
\hline Methylcinnamate & - & $\mathrm{t}$ & $\mathrm{t}$ & - & - \\
\hline Fenchone & - & $\mathrm{t}$ & + & - & - \\
\hline Nerol & + & $\mathrm{t}$ & - & - & + \\
\hline cis-Linalool oxide(furanoid) & + & - & - & - & - \\
\hline Terpinolene & + & + & + & - & + \\
\hline t-Linalool oxide(furanoid) & + & + & + & - & - \\
\hline Linalool & + & + & + & - & + \\
\hline -Ylangene & - & + & - & - & - \\
\hline Linalool acetate & - & $\mathrm{t}$ & + & - & -- \\
\hline Bornyl acetate & - & + & + & - & - \\
\hline 2-Phenyl ethylalcohol & + & + & $\mathrm{t}$ & - & - \\
\hline Camphor & + & $\mathrm{t}$ & + & - & - \\
\hline Citronellal & + & - & - & - & - \\
\hline 2-Phenyl acetaldehyde & - & + & $\mathrm{t}$ & - & - \\
\hline Borneol & + & + & + & + & + \\
\hline Methyl chavicol & + & $\mathrm{t}$ & + & - & - \\
\hline Methyl eugenol & - & $\mathrm{t}$ & - & - & - \\
\hline Methyl isoeugenol & - & - & $\mathrm{t}$ & - & - \\
\hline Ethyl cinnamate & - & - & $\mathrm{t}$ & - & - \\
\hline Methyl cinnamate & - & $\mathrm{t}$ & $\mathrm{t}$ & - & - \\
\hline Z-Methyl cinnamate & + & - & - & - & - \\
\hline Z)-Cinnamaldehyde & + & - & - & - & - \\
\hline Cinnamaldehyde & - & + & + & - & - \\
\hline (E)-Cinnamaldehyde & - & + & + & + & - \\
\hline Geraniol & - & + & + & - & + \\
\hline Piperitone & + & + & + & - & - \\
\hline Safrole & + & $\mathrm{t}$ & + & - & - \\
\hline Benzyl alcohol & - & $\mathrm{t}$ & $\mathrm{t}$ & - & - \\
\hline Eugenol & + & + & + & - & - \\
\hline Isoeugenol & - & + & - & - & - \\
\hline Acetyl eugenol & - & + & + & - & - \\
\hline (Z)-Cinnamyl acetate & + & - & - & - & + \\
\hline (E)-Cinnamyl acetate & - & - & - & + & + \\
\hline Cinnamyl acetate & - & + & $\mathrm{t}$ & - & - \\
\hline Cinnamyl alcohol & - & + & + & - & - \\
\hline Farnesol & - & + & - & - & - \\
\hline (E)- $\beta$-Farnesene & + & - & - & - & + \\
\hline Eugenyl acetate & + & - & - & - & - \\
\hline$\alpha$-Humulene & - & + & + & - & + \\
\hline Cadalene & - & - & - & + & - \\
\hline epi-x-Bisabolol & - & - & - & + & - \\
\hline n-Heptadecane & - & - & - & + & - \\
\hline 2-Heptadecanone & - & - & - & + & - \\
\hline$\alpha$-Selinene & + & - & - & - & - \\
\hline$\beta$-Selinene & - & $\mathrm{t}$ & - & - & - \\
\hline$\delta$-Cadinene & + & - & - & + & + \\
\hline$\alpha$-Cadinene & - & - & - & - & + \\
\hline$\gamma$-Cadinene & - & - & + & - & - \\
\hline Geranial & - & $\mathrm{t}$ & - & - & - \\
\hline
\end{tabular}




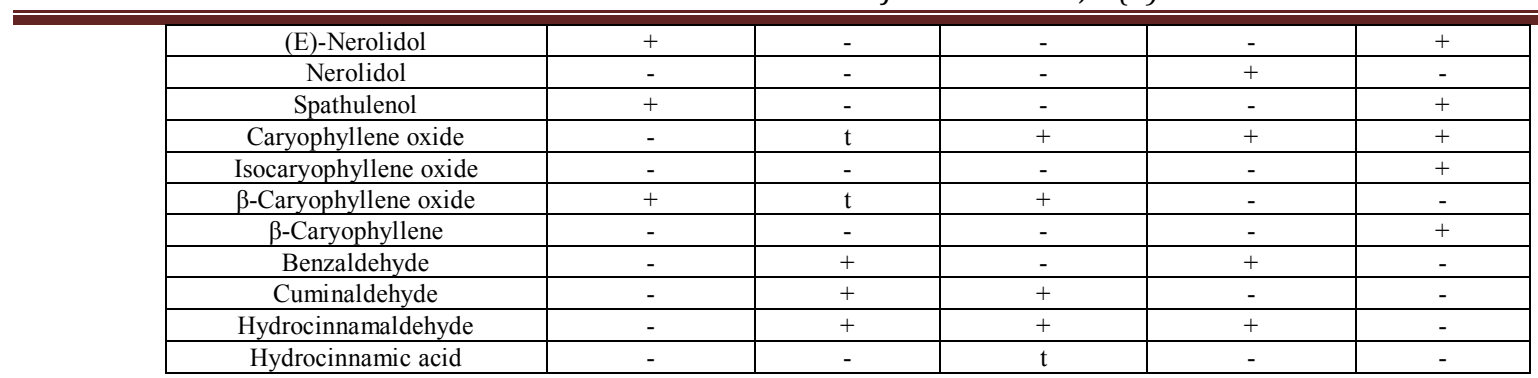

$(+)=$ present, $(-)=$ not present, $\mathrm{t}=$ trace amount present

Table-2 Chemical Composition of Volatile Oil from Cinnamomum zeylanicum Buds ${ }^{35}$

\begin{tabular}{|c|c|c|c|}
\hline SN & Compound & SN & Compound \\
\hline 1. & Heptanal & 15. & $\alpha$-calacorene \\
\hline 2. & $\alpha$-pinene & 16. & Ledol \\
\hline 3. & Nonanal & 17. & Spathuleno \\
\hline 4. & Linalool & 18. & $\alpha$-cadinol \\
\hline 5. & $\alpha$-copaene & 19. & Caryophyllene oxide \\
\hline 6. & $\alpha$-bergamotene & 20. & Globolol \\
\hline 7. & trans-cinnamyl acetate & 21. & Tetradecanol \\
\hline 8. & Aromadendrene & 22. & Epi- $\alpha$-bisabolol \\
\hline 9. & $\alpha$-cadinene & 23. & Torreyol \\
\hline 10. & $\alpha$-humulene & 24. & Benzeyl benzoate \\
\hline 11. & Germacrene-D & 25. & $\gamma$-cadinene \\
\hline 12. & Valencene & 26. & Hexadecanol \\
\hline 13. & Viridiflorene & 27. & $\delta$-cadinene \\
\hline 14. & $\alpha$-muurolene & 28. & S-cis-calamenene \\
\hline
\end{tabular}

\section{CONCLUSION}

There are 70 spices used in different parts of the world .Most of these are grown in India. Initially the spices were only well known as appetizers and essential in the culinary art all over the world. They are used to add taste and flavor to foods .They are also used as preservative in some cases. But presently, spices demand special attention for their varied role in human health. In spite of their traditional use in our country, the plants and their chemical compounds have not been fully investigated to scientifically confirm earlier belief and revel newer medicinal properties and focus on their potential pharmaceutical applications. The present review is therefore an attempt to throw light on the many useful medicinal properties of the said plant and encourage exploitation of the same for human benefit.

\section{REFERENCES}

1. Chopra RN, Nayar SL, Chopra IC.Glossary of Indian Medicinal Plants. Council of Scientific and Industrial Research,New Delhi,1956.

2. Leela NK. Cinnamon and cassia. In: Parthasarathy VA, Chempakam B and Zachariah TJ (eds). Chemistry of spices, Cabi, Wallingford, 2008,chapter -7, p. 124-144.

3. Araar Hakima, Cinnamon plant extracts: a comprehensive physicochemical and biological study for its potential use as a biopesticide,2009, chapter-1,Literature review,Collection Master of Science, p. 562.

4. Lee R. and Balick M J. Sweet wood cinnamon and its importance as a spice and Medicine. Journal of science and healing,2005; 1: 61-64

5. Peter K.V. Handbook of herbs and spices. Woodhead publishing, 2nd edition 2001, vol 1, chapter -10/cinnamon,p.143-153,

6. Asolkar L.V, Kakkar K.K,Chakre O.J, Glossary of Indian Medicinal Plants With Active Principles, National Institute of Science Communications (CSIR), New Delhi,(1956-1981),Part- I,p-204.

7. WHO (World Health Organization). (1999). Cortex Cinnamomi. In: WHO monographs on selected medicinal plants. World Health Organization, Geneva, 1999, vol.1: P. 95-104.

8. Rani P, Venkatesan M, Binilraj J, Sasidha S.S, And Amma P, K. P. Antioxidant and cytotoxic potential of acetone and methanolic extract of C.zeylanicum dry bark. Journal of Cell and Tissue Research 2010; 10(1) 2131-2138.

9. Taker M, Deny Susantib, Mohamad Roji Sarmidia, Fadzilah Adibah Abdul Majida, Hasnah M. Siratb and Farediah Ahmad, Antioxidant Activity of Cinnamtannin B1 from Cinnamomum zeylanicum Blume . Phytomedicines, 2007,p. 601-608
10. Tailing Mukul, Gupta BK, Sharma A . Antidiabetic activity of alcoholic extract of cinnamomum zeylanicum leaves. People' $\mathrm{s}$ journal of scientific research 2008; Vol.1, p.9-11. http://www.iasj.net/iasj func $=$ fulltext \&aId $=30401$

11. Khan A, Bryden NA, Polansky MM, Anderson RA. Biol. Trace Elem. Res. 1990; 24(3):p.183-188. PMid:1702671

12. Imparl-Radosevich J, Deas S, Polansky MM, Baedke DA, Ingebrutsen TS, Anderson RA, Graves DJ. Regulation of phosphorylase phosphatase (PTP-1) and insulin receptor kinase by fractions from cinnamon: implications for cinnamon regulation of insulin signaling. Horm Res. 1998; 50:177-182 http://dx.doi.org/10.1159/000023270 PMid:9762007

13. Jarvill-Taylor KJ, Anderson RA, Graves DJ. A hydroxychalcone derived from cinnamon functions as a mimetic for insulin in 3T3-L1 adipocytes. J Am Coll Nutr 2001;20:327-336 http://www.ncbi.nlm.nih.gov/ pubmed/11506060 PMid:11506060

14. Anderson RA, Broadhurst CL, Polansky MM, Schmidt WF, Khan A,Flanagan VP, Schoene NW and Graves DJ. Isolation andcharacterization of polyphenol type-A polymers from cinnamon with insulinlikebiological activity. Journal agricultural and food chemistry,2004;52:65-70.http://dx.doi.org/10.1021/jf034916b PMid: 14709014

15. Lee H S. Inhibitory activity of Cinnamomum cassiabark derived component against rat lens aldose reductase. Journal of Pharmacy and Pharmaceutical Sciences 2002;5: 226-230. http://europepmc.org /abstract/MED/12553890/reload=0;jsessionid= 70tYzzatLubYTmTQ.6

16. Gende Liesel Brenda, Ignazio F, Rosalia F, Martin J E, Antimicrobial activity of cinnamon(Cinnamomum zeylanicum) essential oil and its main components against Paenibacillus larvae from Argentine, Bulletin of Insectology 2008;61 (1): 1-4.

17. Shan B, Cai YZ, Brooks JD and Corke H Antibacterial properties and major bioactive Components of cinnamon stick (Cinnamomum burmannii): Activity against food borne pathogenic bacteria. Journal agricultural and food chemistry 2007; 55: 5484-5490. http://dx.doi.org/ 10.1021/jf070424d PMid: 17567030

18. Chao SC, Young, DG and Oberg, CJ, Screening for inhibitory activity of essential oils on selected bacteria, fungi and viruses. Journal of Essential Oil Research 2000; 12(5):639-649. http://dx.doi.org/ 10.1080/10412905.2000.9712177

19. Nguyen VM, Nguyen DMC, Seo DJ, Park RD. and Jung WJ. Antimycotic activities of cinnamon-derived compounds against Rhizoctonia solani in vitro. Biological control 2009; (2): 9009-9220.

20. Singh HB, Srivastava M, Singh AB and Srivastava AK, Cinnamon bark oil, a potent fungi toxicant against fungi causing respiratory tractmycoses. Allergy, 1995; 50: 995-999. http://dx.doi.org/10.1111/ j.1398-9995.1995.tb02515.x PMid:8834832

21. Kim SI, Roh JY, Kim DH, Lee HS and Ahn YJ, Insecticidal activities of aromatic plant extracts and essential oils against Sitophilus oryzae (L.) 
and Callosobruchus chinensis (L.). Journal of stored products research 2003a; 39(3):293-303.http://dx.doi.org/10.1016/S0022-474X(02)000176

22. Liu CH, Mishra AK, Tan RX, Tang C, Yang H and Shen YF, Repellent and insecticidal activities of essential oils from Artemisia princeps and Cinnamomum camphora and their effect on seed germination of wheat and broad bean. Bioresource technology, 2005; 97: 1969-1973 PMid: 16230008

23. Park kI, Park JY, Kim KH, Choi IH, Kim CS and Shin SC. Nematicidal activity of plant essential oils and components from garlic (Allium sativum) and cinnamon (Cinnamomum verum) oils against the pine wood nematode (Bursaphelenchus xylophilus). Nematology, 2005;7: 767-774. http://dx.doi.org/10.1163/156854105775142946

24. Kim YH, Khan HU, Kim JH, Jeon YH, Lee EJ and Chang SP. Efficacy of soil amendment with medicinal plant materials for the control of rootknot nematode (Meloidogyne incognita) in tomato. Plant pathology journal, (2003)b; 19(3): 138-142.

25. Chinese Materia Medica (English translation) 1996 ;p. 51.

26. Wang JH Chinese herbal pharmacology. Chinese Materia Medica. Shanghai Science andTechnology Press, Shanghai, China 1985; p. 2728 .

27. Tang W and Eisenbran G, Chinese Drugs of Plant Origin - Chemistry Pharmacology and Use in Traditional Medicine. Springer, Berlin, 1992; p. 319-330.

28. Valero M and Salmeron MC, Antibacterial activity of 11 essential oils against Bacillus cereus in tyndallized carrot broth. International journal of food microbiology, 2003; 85:73-81. http://dx.doi.org/10.1016/S01681605(02)00484-1

29. Tabak M, Armon R, Potasman I and Neeman I. In vitro inhibition of Helicobacter pylori by extracts of thyme. Journal of applied bacteriology, 1996; 80:667-672. http://dx.doi.org/10.1111/j.13652672.1996.tb03272.x PMid:8698668
30. Mancini DAP, Dias ALF, Pinto JR and Mancini FJ. Antioxidant aqueous extract from cinnamon(Cinnamomum zeylanicum, Blume) as inhibitors of influenza virus. Revista Brasileira de Ciencias Farmaceuticas, 1999; 35(1): 155-160.

31. Raina VK, Srivastava SK, Aggarwal KK, Ramesh, S and Kumar S. Essential oil composition ofCinnamomum zeylanicum Blume leaves from Little Andaman, India. Flavour and Fragrance Journal ,2001;16(5): 374-376. http://dx.doi.org/10.1002/ffj.1016

32. Senanayake UM, Lee TH and Wills, RBH. Volatile constituents of Cinnamon (Cinnamomum zeylanicum)oils. Journal of Agriculture and Food Chemistry, 1978; 26: 822-824. http://dx.doi.org /10.1021/jf60218a031

33. Jayaprakasha GK, Rao LJM and Sakariah KK. Chemical composition of the flower oil of Cinnamomum zeylanicum Blume. Journal of Agriculture and Food Chemistry, 2000; 48: 4294-4295. http://dx.doi.org /10.1021/jf991395c PMid:10995352

34. Jayaprakasha GK, Rao, LJ and Sakariah, KK. Chemical composition of the volatile oil from the fruits of Cinnamomum zeylanicum Blume. Flavour and Fragrance Journal, 1997; 12(5): 331-333. http:// dx.doi.org/10.1002/(SICI)1099-1026(199709/10)12:5<331::AIDFFJ663>3.3.CO;2-O

35. Jayaprakasha G K, Lingamallu Jaganmohan Rao and Kunnumpurath $\mathrm{K}$ Sakariah. Chemical Composition of Volatile Oil from Cinnamomum zeylanicum Buds. Z Naturforsch, 2002;57c:990-993. http:// www.znaturforsch.com/ac/v57c/57c0990.pdf

Cite this article as:

Das Manosi, Mandal Suvra, Mallick Budhimanta and Hazra Jayram. Ethnobotany, phytochemical and pharmacological aspects of Cinnamomum zeylanicum Blume. Int. Res. J. Pharm. 2013; 4(4):58-63 